\title{
Energy Metabolism of Human Neutrophils during
}

\section{Phagocytosis}

\author{
Niels BorregaArd and Troels Herlin, Department of Medicine and Infectious \\ Diseases, Department of Dermatology, Marselisborg Hospital; \\ Department of Haematology and Medicine, Aarhus Amtssygehus, \\ DK-8000 Aarhus C., Denmark
}

A B S T R A C T Detailed quantitative studies were performed on the generation and utilization of energy by resting and phagocytosing human neutrophils. The ATP content was $1.9 \mathrm{fmol} /$ cell, was constant during rest, and was not influenced by the presence or absence of glucose in the medium. The intracellular content of phosphocreatine was less than $0.2 \mathrm{fmol} /$ cell.

In the presence of glucose, ATP was generated almost exclusively from lactate produced from glucose taken up from the surrounding medium. The amount of lactate produced could account for $85 \%$ of the glucose taken up by the cells, and the intracellular glycosyl store, glycogen, was not drawn upon. The rate of ATP generation as calculated from the rate of lactate production was $1.3 \mathrm{fmol} / \mathrm{cell} / \mathrm{min}$. During phagocytosis, there was no measurable increase in glucose consumption or lactate production, and the ATP content fell rapidly to $0.8 \mathrm{fmol} / \mathrm{cell}$. This disappearance of ATP was apparently irreversible since no corresponding increase in ADP or AMP was observed. It therefore appears that this phagocytosis-induced fall in ATP concentration represents all the extra energy utilized in human neutrophils in the presence of glucose.

In the absence of glucose, the rate of ATP generation in the resting cell was considerably smaller, $0.75 \mathrm{fmol} /$ cell per min, as calculated from the rate of glycolysis, which is sustained exclusively by glycogenolysis. Under this condition, however, phagocytosis induces significant enhancement of glycogenolysis and the rate of lactate production is increased by $60 \%$, raising the rate of ATP generation to $1.2 \mathrm{fmol} /$ cell per min. Nonetheless, the ATP content drops significantly from 1.9 to $1.0 \mathrm{fmol} /$ cell.

Neutrophils from patients with chronic granulomatous disease have the same rate of glycolysis and

Address reprint requests to Dr. Borregaard at University Hospital, Boston, MA.

Received for publication 4 November 1981 and in revised form 20 April 1982. the same ATP content as normal cells, thus confirming that the defective respiration of these cells does not affect their energy metabolism.

\section{INTRODUCTION}

Neutrophils are important constituents of the motile phagocyte system active against invading microorganisms. These cells expend energy in the performance of active movements both when approaching and engulfing their prey. The energy metabolism of neutrophils has been the subject of many investigations, and it is generally accepted, as first established by Sbarra and Karnovsky (1), that the energy used is derived mainly from glycolysis, although a marked increase in respiration accompanies phagocytosis (2). This respiratory burst of phagocytosis results in the production of toxic oxygen derivatives which participate in the killing of ingested organisms (3-5). The extra energy required for phagocytosis (6) is thought to originate from increased production of lactate, but quantitative data given in the literature vary considerably $(1,7-$ 10). Moreover, most of these previous studies used nonhuman peritoneal exudate cells. We performed quantitative studies of the energy metabolism of human blood neutrophils. Our aim was to measure the rates of ATP production and consumption both during rest and phagocytosis. Determination of intracellular content of ATP in the presence and absence of metabolic inhibitors pointed to a glycolytic origin of the ATP. Rates of glucose consumption, glycogen breakdown, and lactate production were determined in order to quantitate the rate of ATP generation and compare these figures with cellular content of ATP. In addition, the energy metabolism of neutrophils from patients with chronic granulomatous disease was investigated.

\section{METHODS}

Special materials. LDH kits and glucose-hexokinase kits were from Boehringer, Mannheim, West Germany. Dextran 
T-150 was from Pharmacia, Uppsala, Sweden. Fetal calf serum was from Gibco Laboratories, Grand Island Biological Co., Grand Island, NY. Lymphoprep was from Nygaard, Oslo, Norway. Whatman 31 ET was from Whatman, England. ATP monitoring kit and CK kit were from LKB, Bromma, Sweden. ${ }^{3} \mathrm{H}_{2} \mathrm{O},\left[5-{ }^{3} \mathrm{H}\right]$ glucose and $\left[\mathrm{U}-{ }^{14} \mathrm{C}\right]$ glucose-1phosphate were from The Radiochemical Centre, Amersham, England. Amyloglucosidase (EC 3.2.1.3), antimycin A, creatine phosphokinase (EC 2.7.3.2), EDTA, EGTA, lactate dehydrogenase (EC 1.1.1.27), myokinase (EC 2.7.4.3) (rabbit muscle), phosphocreatine, phospho-enol-pyruvate, pyruvate kinase (EC 2.7.1.40) (rabbit muscle), Tris, Triton $\mathrm{X}-100$, and zymosan A were from Sigma Chemical Co., St. Louis, MO. Latex particles (Diam $0.81 \mu \mathrm{m}$ ) were from Difco Laboratories, Detroit, MI. Ready-Solv for scintillation counting was from Beckman, Copenhagen, Denmark. PPO $(2,5$ diphenyl oxazole) was from E. Merck, Darmstadt, West Germany. Serum-treated zymosan was prepared using pooled human serum as described (11). Immunoglobulin G-coated latex particles were prepared as described (11).

Isolation of cells. Blood, $25-500 \mathrm{ml}$, was withdrawn from patients and healthy controls giving informed consent. The blood was heparinized, $40 \mathrm{IU} / \mathrm{ml}$, and dextran T-150, $1 \mathrm{~g} /$ $100 \mathrm{ml}$, was added. After standing at room temperature for $30 \mathrm{~min}$ for the erythrocytes to sediment, the leukocyte-rich supernate was aspirated, layered on Ficoll-Isopaque (Lymphoprep), and centrifuged at $800 \mathrm{~g}$ for $15 \mathrm{~min}$ in a Sigma 3 E-1 centrifuge. The granulocyte-erythrocyte pellet was gently suspended in $10 \mathrm{ml}$ distilled water for lysis of contaminating erythrocytes. Isotonicity was restored after $30 \mathrm{~s}$ by addition of $30 \mathrm{ml} \mathrm{NaCl}, 12 \mathrm{~g} /$ liter. The neutrophils were then washed twice in Hanks' balanced salt solution containing $25 \mathrm{mM}$ Hepes pH 7.4 without glucose (Hanks'-Hepes buffer) and finally resuspended in Hanks'-Hepes buffer in a concentration of $1 \times 10^{7}$ cells $/ \mathrm{ml}$ and placed in an ice water bath until experiments were carried out. Judged by morphological criteria, the neutrophil suspension was $>97 \%$ pure, and judged by trypan blue exclusion, $>98 \%$ of the cells were viable.

Lactate production. Cells were pelleted in conical tubes and placed on ice. Immediately before use, the supernate was aspirated and the cells resuspended to a concentration of $2.0 \times 10^{7}$ cells $/ \mathrm{ml}$ in prewarmed Hanks'-Hepes buffer with additions as indicated and placed in a thermostatically controlled, rapidly stirred chamber at $37^{\circ} \mathrm{C}$. Samples of 200 $\mu \mathrm{l}$ were withdrawn at the times indicated and immediately mixed with $100 \mu \mathrm{l} 0.6 \mathrm{M}$ perchloric acid. The precipitate was pelleted by centrifugation and lactate in the supernate was measured spectrophotometrically as described (12) by following the generation of NADH in the presence of lactate dehydrogenase and hydrazine. Briefly, $50 \mu$ l supernate was mixed with $100 \mu \mathrm{l} 27 \mathrm{mM} \mathrm{NAD}^{+}$and $1000 \mu \mathrm{l} 0.4 \mathrm{M}$ hydrazine, $0.5 \mathrm{M}$ glycine, $\mathrm{pH} 9.0$ in both reference and sample cuvettes. The reaction was initiated by adding $10 \mu$ l lactate dehydrogenase $(100 \mathrm{U})$ to the sample cuvette and an equal amount of buffer to the reference. After $80 \mathrm{~min}$ at room temperature, the difference in absorbance between sample and reference was read at $340 \mathrm{~nm}$. Assays were run in triplicate. Standards containing known amounts of lactate were always included as reference. At the time indicated, serumtreated zymosan $(S T Z)^{1}$ (final concentration of $4 \mathrm{mg} / \mathrm{ml}$ ) or an equal volume of buffer was added.

Flux through Embden-Meyerhof pathway. In order to

\footnotetext{
${ }^{1}$ Abbreviations used in this paper: PMA, phorbol myristate acetate; STZ, serum-treated zymosan particles.
}

detect rapid changes in the flux of glucose through the Embden-Meyerhof pathway, the method of Ashcroft et al. (13) for estimation of glucose flux in pancreatic beta cells was adapted to human neutrophils. The method is based on the exchange of ${ }^{3} \mathrm{H}$ from $\left[5-{ }^{3} \mathrm{H}\right]$ glucose to ${ }^{3} \mathrm{H}_{2} \mathrm{O}$ when phosphoenol pyruvate is formed. $2 \mathrm{ml}$ of neutrophil suspension, 2 $\times 10^{6}$ cells $/ \mathrm{ml}$ in Hanks'-Hepes buffer containing $5 \mathrm{mM}$ glucose and other additions as indicated were incubated for 10 min at $37^{\circ} \mathrm{C}$ in a rapidly stirred, thermostatically controlled chamber. Then $100 \mu \mathrm{l}$ of $0.1 \mathrm{mM}\left[5-{ }^{3} \mathrm{H}\right]$ glucose (sp act 100 $\mathrm{mCi} / \mu \mathrm{mol})$ and, immediately after this, either $100 \mu \mathrm{l}$ buffer or $100 \mu \mathrm{l} \mathrm{STZ}(0.5 \mathrm{mg} / \mathrm{ml})$ were added. Samples of $50 \mu \mathrm{l}$ were then withdrawn at times indicated and immediately mixed with $200 \mu \mathrm{l} 1 \mathrm{M} \mathrm{HCl}$ in the center well of conical flasks. A rubber cap immediately sealed the flasks, which were then placed in a $37^{\circ} \mathrm{C}$ water bath with shaking to allow ${ }^{3} \mathrm{H}_{2} \mathrm{O}$ present in the center well to equilibrate with $2 \mathrm{ml}$ of water present outside the center well. After $14 \mathrm{~h}, 1 \mathrm{ml}$ of the water was aspirated, mixed with $10 \mathrm{ml}$ Ready-Solv, and counted in a Packard Tricarb Scintillation Counter (Packard Instrument Co., Inc., Downers Grove, IL). At least 10,000 counts were made on each sample. A control experiment with ${ }^{3} \mathrm{H}_{2} \mathrm{O}$ ascertained that $85 \pm 2.5 \%$ (SEM, $n=6$ ) of the ${ }^{3} \mathrm{H}_{2} \mathrm{O}$ originally present in the center well was present in the surrounding water after $14 \mathrm{~h}$. Backgrounds were kept low by evaporating the $\left[5-{ }^{3} \mathrm{H}\right]$ glucose and redissolving it in water immediately before use.

Determination of glucose, glycogen, and phosphorylase activity. Cells were incubated at $37^{\circ} \mathrm{C}$ in Hanks'-Hepes buffer with additions as indicated in a concentration of 5 $\times 10^{7}$ cells $/ \mathrm{ml}$ in conical siliconized glass flasks in a thermostatically controlled water bath with shaking. At intervals, $400-\mu$ l samples were withdrawn, mixed with $100 \mu$ ice-cold buffer (250 mM Tris, pH 7.2 [at $20^{\circ} \mathrm{C}$ ], $25 \mathrm{mM}$ EGTA, 25 $\mathrm{mM}$ EDTA, $250 \mathrm{mM} \mathrm{NaF}$ ) in precooled centrifuge tubes and immediately sonicated by applying $20 \mathrm{kHz}$, amplitude 12 $\mu \mathrm{m}$ for $20 \mathrm{~s}$. STZ was added as indicated in Results to a final concentration of $5 \mathrm{mg} / \mathrm{ml}$. After sonication, the samples were centrifuged in the cold at $1,500 \mathrm{~g}$ for $20 \mathrm{~min}$. The supernate was then aspirated and analyzed for glucose, glycogen, and phosphorylase a activity. Glucose was measured by the hexokinase method using the Boehringer kit except that deproteinization was omitted.

Glycogen was measured by the filter paper technique of Sølling and Esmann (14). Briefly, $50 \mu \mathrm{l}$ of the supernates were spotted on filter paper squares (Whatman $37 \mathrm{ET}$ ) and submerged in ice-cold $66 \%$ ethanol. After extensive washing in $66 \%$ ethanol at room temperature, the filter papers were dried and submerged in $300 \mu \mathrm{l} 0.1 \mathrm{M}$ acetate, $\mathrm{pH}$ 4.75. 30 $\mu$ l containing amyloglucosidase $(30 \mathrm{mU})$ were then added and the amount of glucose liberated after $10 \mathrm{~min}$ at room temperature was determined by the hexokinase method. Assays were run in duplicate. Standards containing known amounts of glycogen were always included as reference.

Phosphorylase (EC 2.4.1.1) was measured in the direction of glycogen synthesis using the filter paper method of Wang and Esmann (15). Using $10 \mathrm{mM}\left[\mathrm{U}-{ }^{14} \mathrm{C}\right] \mathrm{g}$ lucose-1-phosphate, sp act $100,000 \mathrm{dpm} / \mu \mathrm{mol}$ and omitting AMP from the reaction mixture, the assay is specific for the phosphorylated form of glycogen phosphorylase, phosphorylase a (N. Borregaard, unpublished observation). The incorporation of $\left[{ }^{14} \mathrm{C}\right]$ glucose from [U-14 $\mathrm{C}$ ]glucose-1-phosphate into glycogen was carried out at $30^{\circ} \mathrm{C}$ in a volume of $90 \mu \mathrm{l}$. After incubation for $10 \mathrm{~min}, 75 \mu \mathrm{l}$ was withdrawn and spotted on filter paper squares (Whatman $31 \mathrm{ET}$ ) that were immediately submerged in ice-cold $66 \%$ ethanol for the glycogen to precipitate in the filters. After extensive washing in $66 \%$ ethanol 
at room temperature, the filter papers were dried and counted in toluene containing $0.5 \mathrm{~g} / 100 \mathrm{ml}$ PPO $(2.5 \mathrm{di}$ phenyl oxazole) in a Packard Tricarb Scintillation Counter. Duplicate assays were run. $1 \mathrm{U}$ of enzyme is the amount that incorporates $1 \mu \mathrm{mol}$ of substrate into glycogen per minute at $30^{\circ} \mathrm{C}$

Determination of ATP/ADP/AMP. Adenine nucleotides were measured using a luminometric method based on firefly luciferase. Cells were incubated in Hanks'-Hepes buffer with additions as indicated in a concentration of $2 \times 10^{6}$ cells $/ \mathrm{ml}$ in a rapidly stirred thermostatically controlled chamber at $37^{\circ} \mathrm{C}$. At the times indicated, $150 \mu$ l was withdrawn and instantly frozen by spotting on the bottom of glass tubes submerged in dry ice. At the end of the experiments, $1,000 \mu \mathrm{l}$ of buffer, $100 \mathrm{mM}$ Tris, pH 7.75 (at $20^{\circ} \mathrm{C}$ ), 2 mM EDTA (Tris-EDTA buffer) was added to each frozen sample and sonication was immediately carried out by applying $20 \mathrm{kHz}$, amplitude $12 \mu \mathrm{m}$ for $20 \mathrm{~s}$. Control experiments showed that adenine nucleotides added to samples before freezing were quantitatively recovered, and that freezing did not alter the amounts of nucleotides recovered from the cells. The nucleotide levels were constant for several hours at room temperature after sonication. The amount of extractable adenine nucleotides was unaffected by addition of Triton X-100 or deproteinization with perchloric acid or trichloric acetic acid. After sonication, the samples were further diluted by addition of 2,000 $\mu$ l Tris-EDTA buffer and divided in three for the determination of ATP, ATP + ADP, and ATP + ADP + AMP, respectively.

ATP was measured by mixing $800 \mu$ l extract with 200 $\mu \mathrm{l}$ of ATP monitoring reagent (ATP Monitoring Kit. LKB). The luminescence was measured at room temperature in an LKB luminometer. ATP + ADP was measured by incubating $750 \mu$ l extract with $10 \mu \mathrm{l}$ pyruvate kinase, $5,000 \mathrm{U} / \mathrm{ml}, 40$ $\mu \mathrm{l} 2.5 \mathrm{mM}$ phospho-enol pyruvate, $0.5 \mathrm{mM} \mathrm{MgSO}_{4}, 0.5 \mathrm{mM}$ $\mathrm{K}_{2} \mathrm{SO}_{4}$ for $15 \mathrm{~min}$ at $20^{\circ} \mathrm{C}$ and then adding $200 \mu \mathrm{l} \mathrm{ATP}$ monitoring reagent. ATP + ADP + AMP was measured by incubating $740 \mu \mathrm{l}$ extract with $10 \mu \mathrm{l}$ myokinase, $2,500 \mathrm{U} / \mathrm{ml}$ and further addition as for ATP + ADP measurement. The mixture was incubated at $37^{\circ} \mathrm{C}$ for $30 \mathrm{~min}$ and allowed to cool to room temperature before ATP monitoring reagent was added. In the reaction mixture, AMP is converted to ADP in the reaction catalyzed by myokinase: AMP + ADP $\rightleftarrows 2$ ADP. The ADP formed is then quantitatively converted to ATP in the reaction catalyzed by pyruvate kinase. As an overall result, AMP is stoichiometrically converted to ATP with no net consumption of ATP or ADP. In all conditions investigated, sufficient amounts of ATP were present to initiate the myokinase reaction since control experiments showed that addition of ATP did not alter the net amounts of ATP recovered.

Phosphocreatine. For measurement of phosphocreatine, cells were incubated in a concentration of $1 \times 10^{8}$ cells $/ \mathrm{ml}$ in Hanks'-Hepes buffer containing $5 \mathrm{mM}$ glucose. At the times indicated, $400 \mu \mathrm{l}$ were withdrawn and mixed with 400 $\mu l 10 \%$ trichloroacetic acid. The precipitate was pelleted by centrifugation and the supernate was withdrawn and extracted with ether five times. Phosphocreatine was then measured kinetically in dilutions of this extract by following the generation of ATP in the presence of creatine phosphokinase using the CK kit of LKB as follows: It was ascertained that added commercial phosphocreatine was quantitatively recovered after the precipitation and extraction steps. 900 $\mu \mathrm{l}$ of CK reagent containing firefly luciferase in buffer was mixed with $20 \mu \mathrm{l}$ creatine phosphokinase $(200 \mathrm{mU} / \mathrm{ml})$ and $20 \mu \mathrm{l}$ ADP substrate and incubated for $15 \mathrm{~min}$ at room temperature; $60^{\circ} \mu$ l extract or phosphocreatine was then added and the luminescence in the LKB luminometer continuously recorded on a chart recorder. By using commercial phosphocreatine, it was established that the slopes of the curves obtained after addition of samples were proportional to the phosphocreatine concentration in the range of $0.005-1 \mathrm{mM}$ and that the slopes of the curves were unaffected by addition of ATP. The starting points of the curves were shifted upwards proportional to the amounts of ATP added as expected.

Chronic granulomatous disease patients. The diagnosis of chronic granulomatous disease was based on the following criteria referring to neutrophil function: $(a)$ defective killing of Staphylococcus aureus despite normal phagocytosis; (b) no increase in oxygen consumption following phagocytosis of STZ; (c) no liberation of superoxide anions upon stimulation by phorbol myristate acetate (PMA); and (d) normal content of glucose-6-phosphate dehydrogenase, 6-phosphogluconate dehydrogenase, glutathione reductase and glutathione peroxidase. The inheritance was determined as $\mathrm{X}$ linked by the demonstration of a carrier state in the mothers using a PMA-stimulated nitroblue tetrazolium slide test (16), and as autosomal recessive when the patient was a female and no carrier state could be detected in the mother.

\section{RESULTS}

Adenine nucleotides. The intracellular content of ATP in human neutrophils was found to be $1.9 \pm 0.1$ $\mathrm{fmol} / \mathrm{cell}(\mathrm{SEM}, n=12)$. This level remains nearly constant during $45 \mathrm{~min}$ of incubation either in the presence or absence of glucose, although in the presence of glucose the ATP concentration apparently declines slightly (Fig. 1). Addition of a phagocytic stimulus, STZ, however, induces a rapid reduction of the cellular content of ATP of $0.25 \mathrm{fmol} /$ cell per min as calculated from the slope at the inflexion point. The fall in ATP concentration is linear for $\sim 3 \mathrm{~min}$ and then levels off to reach a new steady state level of 0.8 fmol/cell. The ATP concentration does not climb to the initial value after prolonged incubation $(2 \mathrm{~h})$, even if nonadherent particles have been removed by washings. Exactly the same response was observed upon addition of immunoglobulin G-coated latex particles (IgG-latex particles), $10^{9}$ particles/ml (data not shown).

Omission of glucose from the incubation medium did not result in a more rapid depletion of cellular ATP following phagocytosis. On the contrary, cellular ATP was slightly higher in resting neutrophils and the phagocytosis-induced decrease was less pronounced when glucose was absent $(0.16 \mathrm{fmol} /$ cell per min). Addition of $5 \mathrm{mM}$ 2-deoxyglucose rapidly depleted the cell of ATP and abolished the phagocytosis-induced ATP response. The fall in cellular ATP concentration secondary to addition of 2-deoxyglucose was apparently irreversible since the ATP concentration did not increase during incubation of cells in the presence of $5 \mathrm{mM}$ glucose after 2-deoxyglucose had been removed by washing twice (data not shown). Incubation with the thiol reacting agents, iodoacetamide and $\mathrm{N}$-ethyl- 


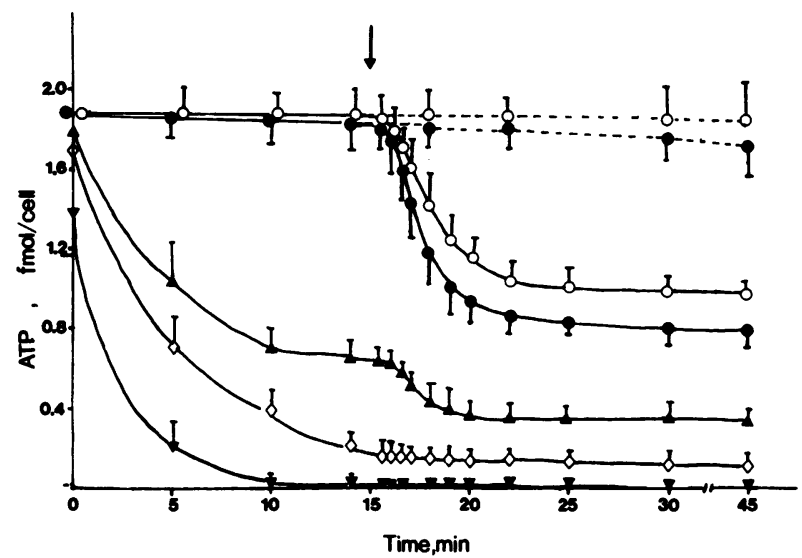

Figure 1 Intracellular ATP concentration during rest and phagocytosis in the absence and presence of metabolic inhibitors. Experimental conditions were as described in Methods. Cells were incubated in a concentration of $2 \times 10^{6}$ cells/ $\mathrm{ml}$ in Hanks'-Hepes buffer with additions as indicated by symbols. At time as indicated by arrow, addition was made of either serum-treated zymosan to a final concentration of $0.5 \mathrm{mg} / \mathrm{ml}$ or of an equal volume of buffer. Each point is the mean of four independent experiments. Bars indicate SEM. Symbols: $O$ No addition; $5 \mathrm{mM}$ glucose; $\Delta 1 \mathrm{mM}$ iodoacetamide and $5 \mathrm{mM}$ glucose; $\nabla 1 \mathrm{mM} N$-ethyl-maleimide and $5 \mathrm{mM}$ glucose; $\diamond 5 \mathrm{mM}$ 2-deoxyglucose; $\cdots$ indicates buffer was added instead of STZ at time indicated by arrow.

maleimide, which are generally used as inhibitors of glycolysis, resulted in reduction of cellular ATP concentration and of the response to a phagocytic stimulus.

The mitochondrial inhibitors, cyanide and azide, in concentrations of $1 \mathrm{mM}$ and antimycin $A$ in a concentration of $10 \mu \mathrm{M}$, had no effects on resting ATP level or on the response to addition of STZ either in the presence or absence of glucose (data not shown).

Fig. 2 shows that the decrease in cellular ATP concentration, whether induced by phagocytosis or by addition of 2-deoxyglucose, is not accompanied by any increase in ADP and AMP concentrations, which are virtually constant during phagocytosis and decrease slightly following addition of 2-deoxyglucose. Thus, the fall in total adenine nucleotides is solely accounted for by the fall in ATP.

Phosphocreatine. By using a kinetic assay where the rate of ATP formation from phosphocreatine is measured in the presence of creatine phosphokinase, a linear dose-response curve was obtained for phosphocreatine in the range of 0.005 to $1 \mathrm{mM}$. ATP present in the cellular extract was carried over into the phosphocreatine assay and immediately reacted with the luciferase to give an increase in luminescence corresponding to the amount of ATP present. A limit was therefore set for the concentration of extracts that

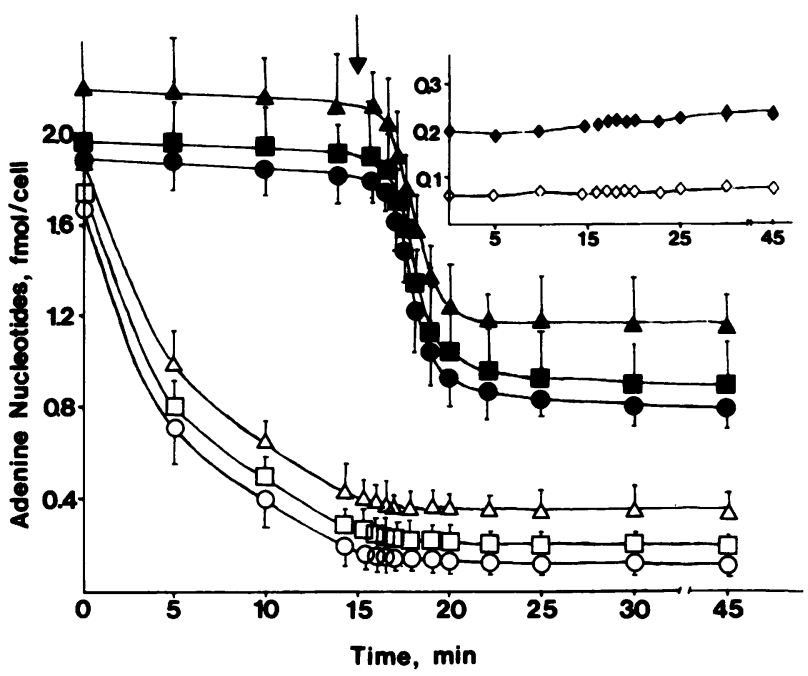

Figure 2 Intracellular concentration of ATP, ADP, and AMP during rest and phagocytosis. Experimental conditions as described in Methods. Cells were incubated in a concentration of $2 \times 10^{6}$ cells $/ \mathrm{ml}$ in Hanks'-Hepes buffer with additions as indicated by symbols in the presence of either 5 $\mathrm{mM}$ glucose (solid symbols) or $5 \mathrm{mM}$ 2-deoxyglucose (open symbols, main figure). At time as indicated by arrow, serumtreated zymosan was added to a final concentration of $\mathbf{0 . 5}$ $\mathrm{mg} / \mathrm{ml}$. Symbols: OO is ATP; $\square$ is ATP + ADP; $\triangle \Delta$ is ATP + ADP + AMP. Open symbols indicate that $5 \mathrm{mM}$ 2-deoxyglucose is present. Closed symbols indicate that $5 \mathrm{mM}$ glucose is present. Each point is the mean of four independent experiments. Bars indicate SEM. Inset: The concentration of ADP and AMP are given as calculated from the main figure by subtracting $\square$ from $\Delta$ for AMP, and $\bigcirc$ from $\square$ for ADP; $\checkmark$ is AMP $\diamond$ is ADP.

could be assayed for phosphocreatine. If the extract concentration did not exceed the equivalent of $3 \times 10^{7}$ cell $/ \mathrm{ml}$, the assay remained sufficiently sensitive to detect $5 \mu \mathrm{M}$ added phosphocreatine. Since none was, in fact, detected in the extract of $3 \times 10^{7}$ cells $/ \mathrm{ml}$, the amount of phosphocreatine in the $1 \mathrm{ml}$ reaction mixture was $<5 \mu \mathrm{mol}$ and the amount per cell was $<0.17$ fmol.

Glycolysis. The turnover of ${ }^{3} \mathrm{H}$ from $\left[5-{ }^{3} \mathrm{H}\right]$ glucose to ${ }^{3} \mathrm{H}_{2} \mathrm{O}$ was linear with time for $20 \mathrm{~min}$ and linear with cell concentration in the range of $10^{5}$ to $10^{7}$ cells/ $\mathrm{ml}$. This parameter was unaffected by addition of a phagocytic stimulus and, even during the first seconds after activation of the cells, no increase could be observed in the presence of glucose. Since the turnover of $\left[5^{3} \mathrm{H}\right]$ glucose to ${ }^{3} \mathrm{H}_{2} \mathrm{O}$ is a measure of the production of phospho-enol pyruvate, these results indicate that the activity of the Embden-Meyerhof pathway is unchanged during phagocytosis in the presence of glucose.

Direct measurements of lactate production confirmed the observation that in the presence of glucose, 
addition of STZ as a phagocytic stimulus did not intensify lactate production, which was measured to be $1.3 \mathrm{fmol} /$ cell per min, as calculated from the slope of the curve in Fig. 4. Neither did addition of IgG-latex $\left(4 \times 10^{9}\right.$ particles $\left./ \mathrm{ml}\right)$ as a phagocytic stimulus intensify the lactate production (data not shown).

In the absence of glucose, the lactate production was significantly reduced $(0.51 \mathrm{fmol} /$ cell per min, as calculated from the slope of the curve in Fig. 4). However, in this situation, addition of a phagocytic stimulus induced an immediate increase of nearly $60 \%$ in the rate of lactate production.

Glucose consumption. As seen from Fig. 5, glucose consumption by neutrophils is linear with time and is not increased when the cells are induced to phagocytosis by addition of STZ. A glucose consumption of $0.84 \mathrm{fmol} /$ cell per min was calculated from the figure.

Glycogenolysis. Fig. 5 shows that very little depletion of the endogenous glycosyl reservoir, glycogen, occurs in neutrophils when glucose is present in the buffer medium. Even during phagocytosis, there is no measurable increase in glycogenolysis. However, in the absence of glucose, glycogen is broken down at a rate corresponding to the formation of $2.4 \times 10^{-16}$ glycosylic units per cell per min, and addition of STZ enhances this rate of glycogenolysis three to fourfold. However, the rate of glycogenolysis is not linear with time and gradually levels off.

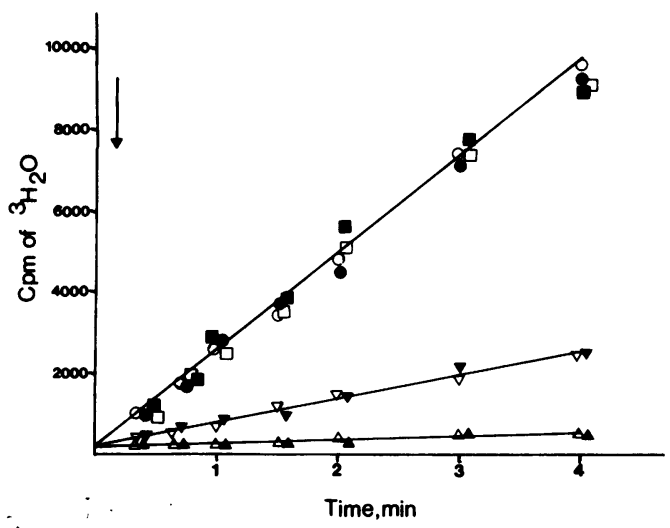

Figure 3 Turnover of ${ }^{3} \mathrm{H}$ from $\left[5-{ }^{3} \mathrm{H}\right]$ glucose to ${ }^{3} \mathrm{H}_{2} \mathrm{O}$. Experimental conditions as described in Methods. Cells were preincubated in a concentration of $2 \times 10^{6}$ cells per $\mathrm{ml}$ in Hanks'-Hepes buffer containing $5 \mathrm{mM}$ glucose for $10 \mathrm{~min}$ with addition as indicated by symbols. At time $0\left[5-{ }^{3} \mathrm{H}\right] \mathrm{glucose}$ was added in trace amounts. At time as indicated by arrow addition was made of either STZ to a final concentration of $0.5 \mathrm{mg} / \mathrm{ml}$ or of an equal volume of buffer. Symbols: 0 No additions made. $1 \mathrm{mM} \mathrm{KCN} ; \nabla \nabla 1 \mathrm{mM}$ iodoacetamide; $\Delta \Delta 1 \mathrm{mM} N$-ethyl-maleimide. Solid symbols represent addition of STZ. Open symbols represent addition of buffer alone. Each point is the mean of four independent experiments. Standard error of the mean did not exceed $10 \%$ of the mean.

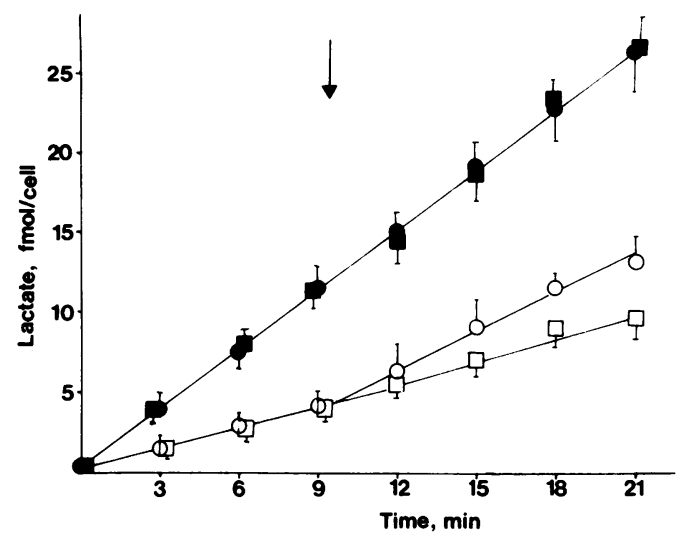

Figure 4 Production of lactate by resting and phagocytosing neutrophils in the presence and absence of glucose. Experimental conditions as described in Methods. Cells were pelleted and resuspended to a cell concentration of $\sim 2 \times$ $10^{7}$ cells/ml in Hanks'-Hepes buffer either with (solid symbols) or without (open symbols) $5 \mathrm{mM}$ glucose. Samples were withdrawn at time intervals and analyzed for lactate. The lactate produced per cell was then calculated and the figures plotted. At the time indicated by arrow, addition was made of either serum-treated zymosan to a final concentration of $4.0 \mathrm{mg} / \mathrm{ml}$ (circles) or of an equal amount of buffer (squares). Each point is the mean of four independent experiments. Symbols: $5 \mathrm{mM}$ glucose present, STZ added; $5 \mathrm{mM}$ glucose present, buffer added; $\bigcirc$ glucose omitted, STZ added; $\square$ glucose omitted, buffer added.

As seen from Fig. 6, phosphorylase a, the effector enzyme of glycogenolysis, is inactivated following addition of $5 \mathrm{mM}$ glucose and remains inactive in the resting cell. Addition of STZ, however, induces a flash activation of phosphorylase. In the absence of glucose, the level of phosphorylase a activity in the resting cell is significantly higher, and addition of STZ induces a rapid activation of phosphorylase a activity that lasts longer than in the presence of glucose.

Chronic granulomatous disease. The ATP concentration during rest and the drop subsequent to phagocytosis were both normal in neutrophils from patients with either the autosomal recessive or the X-linked form of chronic granulomatous disease. The rate of glycolysis measured as ${ }^{3} \mathrm{H}_{2} \mathrm{O}$ formation from [5$\left.{ }^{3} \mathrm{H}\right]$ glucose was also normal in these patients (data not shown).

\section{DISCUSSION}

The results demonstrate that the ATP concentration in the human neutrophil is not dependent on mitochondrial activity, whereas addition of glycolytic inhibitors reduces intracellular ATP. This strongly indicates that the human neutrophil derives energy mainly from glycolysis. This conclusion has been drawn before by other investigators working with neu- 


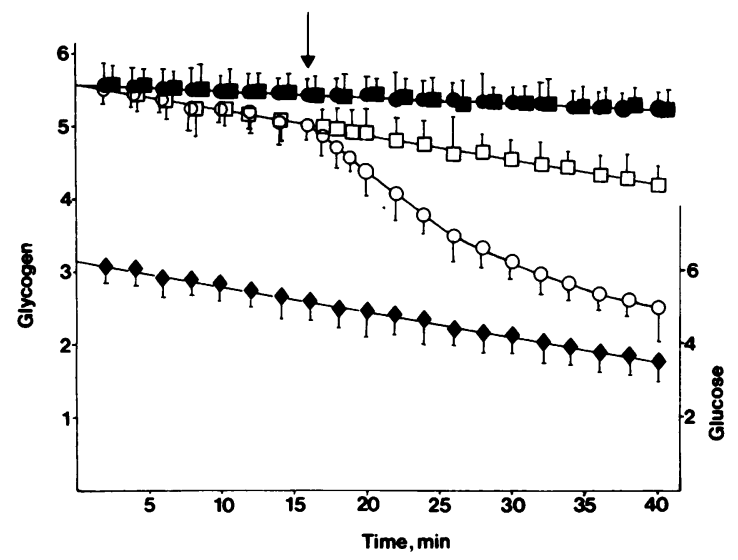

Figure 5 Consumption of glucose (millimoles per liter) and of glycogen (picograms per cell) by human neutrophils in the presence and absence of glucose. Cells, $5 \times 10^{7} / \mathrm{ml}$ in Hanks'-Hepes buffer, were incubated with (solid symbols) or without (open symbols) $5 \mathrm{mM}$ glucose added. At time intervals, samples were withdrawn and the cells immediately disrupted by sonication. After centrifugation of the samples, glucose and glycogen were determined in the supernates as described in Methods. The amount of glycogen per cell was calculated and the figures plotted. The glucose concentration of the samples was plotted. At the time indicated by arrow, either serum-treated zymosan was added to a final concentration of $5 \mathrm{mg} / \mathrm{ml}$ (circles) or an equal volume of buffer (squares). Corrections have been made for the dilution of cells and glucose. Each point is the mean of three independent experiments. Bars indicate SEM. Symbols: $O \square$ indicate intracellular glycogen to be read at left ordinate; $\bullet$ indicates glucose concentration to be read at right ordinate; - $5 \mathrm{mM}$ glucose present, STZ added; $5 \mathrm{mM}$ glucose present, buffer added; $\bigcirc$ glucose omitted, STZ added; $\square$ glucose omitted, buffer added.

trophils from different sources [guinea pig $(1,17)$, rabbit (7), rat (8), man (18)]. The ATP generation in the cells may, therefore, be calculated from the rate of lactate production.

In the presence of glucose, endogenous glycogen is not significantly degraded as also observed before (19, 20 ) and each mole of lactate produced, therefore, represents $1 \mathrm{~mol}$ of ATP formed from ADP. The finding of a lactate production of $1.3 \mathrm{fmol} / \mathrm{cell}$ per $\mathrm{min}$, which is in agreement with previous reports $(21,22)$, therefore indicates a turnover of ATP of $1.3 \mathrm{fmol} /$ cell per min. The steady state concentration of ATP of 1.9 $\mathrm{fmol} /$ cell agrees well with previous findings in human cells (23-25).

During phagocytosis, the ATP concentration drops to $0.8 \mathrm{fmol} /$ cell during the first $5 \mathrm{~min}$ of phagocytosis after which a steady level is reached. The period of time corresponds with the time during which phagocytosis takes place (26). We were unable to measure any increase in lactate production by the cell when phagocytosis was initiated. Sbarra and Karnovsky (1)

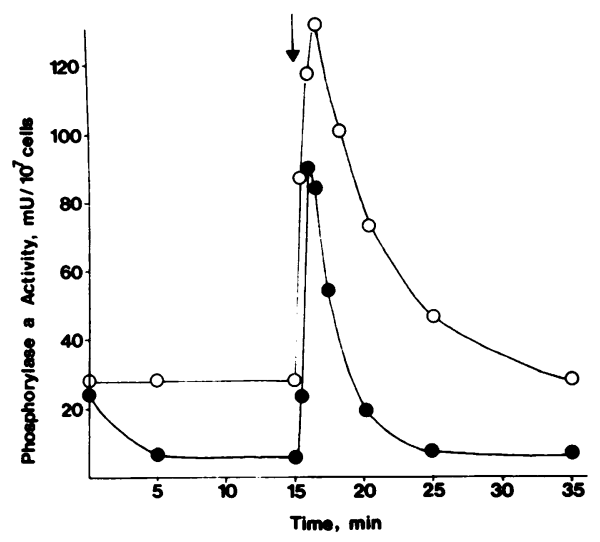

FIgure 6 Phosphorylase a activity in resting and phagocytosing human neutrophils. Experimental conditions as described in Methods. Cells, $5 \times 10^{7} / \mathrm{ml}$ in Hanks'-Hepes buffer, were incubated in either the presence (solid symbols) or absence (open symbols) or $5 \mathrm{mM}$ glucose. Samples were withdrawn at time intervals and the cells immediately disrupted by sonication. After centrifugation, phosphorylase a activity was measured in the supernates. At the time indicated by arrow, serum-treated zymosan was added to a final concentration of $5 \mathrm{mg} / \mathrm{ml}$. Control experiments not shown revealed that addition of buffer instead of STZ did not result in any alteration of phosphorylase a activity. Each point is the mean of three independent experiments. Symbols: 5 $\mathrm{mM}$ glucose present; $O$ glucose omitted.

measured a twofold increase in lactate production by phagocytosing guinea pig exudate cells, whereas Reed and Tepperman were unable to observe any increase using rat exudate cells (8). Roos and Stijl-Neijenhuis observed a $20 \%$ increase in lactate production in human cells during phagocytosis (27).

Our finding is supported by the independent observations that glucose uptake, $80 \%$ of which is accounted for by lactate formation, is not increased by phagocytosis, and that endogenous glycogen is not mobilized by the flash activation of phosphorylase. These results carry the drawback that any changes observed during phagocytosis are superimposed on the values from the resting period. However, the turnover of $\left[5-{ }^{3} \mathrm{H}\right] g l u c o s e$ to ${ }^{3} \mathrm{H}_{2} \mathrm{O}$, because of rapid equilibration of glucose across the leukocyte plasma membrane (28), permits estimation of the flux rate in the Embden-Meyerhof pathway at any time during the incubation, and the finding that this turnover is not changed by phagocytosis independently indicates a constant rate of glycolysis. Therefore, it seems safe to conclude that the rate of formation of ATP from carbohydrates is not increased during phagocytosis. The finding of a phosphocreatine concentration $<0.2 \mathrm{fmol} /$ cell excludes this compound as a major donor of energy. Consequently, the drop of ATP from 1.9 to $0.8 \mathrm{fmol} / \mathrm{cell}$ during phagocytosis represents the extra amount of 
energy consumed in this activity; since this ATP is used during 3-5 min, there is an increase in ATP consumption of roughly $20 \%$ per min. Since this extra ATP consumed liberates $2 \mathrm{~mol}$ of high energy phosphates per mole of ATP (see below), the increase in energy consumption per min is $40 \%$ during the first minutes of phagocytosis. Loike et al. (29) found phosphocreatine to be present in a concentration of three to five times the ATP concentration in mouse peritoneal macrophages, and argued that this, under certain conditions, provided the energy for phagocytosis. Unfortunately, the ATP generation was not given to assess the significance of this pool of high energy phosphate, but the results demonstrate a clear difference between macrophages and neutrophils.

In the absence of glucose, lactate production is significantly lower but, since in this situation glucose-6phosphate is formed from glycogen without use of high energy phosphate, each mole of lactate produced represents $1.5 \mathrm{~mol}$ of ATP formed from ADP. The calculated rate of ATP generation, therefore, becomes $0.75 \mathrm{fmol} /$ cell per min, which is considerably less than the generation observed in the presence of glucose. During phagocytosis in glucose-free medium, there is a significant increase in glycogenolysis caused by a sustained activation of glycogen phosphorylase and a $60 \%$ increase in lactate production. The resulting calculated rate of ATP generation of $1.2 \mathrm{fmol} /$ cell per min is slightly less than that calculated for cells in the presence of glucose. Unexpectedly, the ATP concentration is kept equally high as in the presence of glucose, but the phagocytosis-induced fall is more sluggish and this adds to the difference in high energy phosphate consumption during phagocytosis in the presence and absence of glucose.

The results with CGD patients demonstrate that lack of oxidase function does not affect the energy metabolism of these cells, which is in accordance with the normal phagocytic and chemotactic activity most often observed in these patients $(30,31)$.

The phagocytosis-associated fall in intracellular ATP concentration in human neutrophils has been observed by others $(10,24)$, although some earlier investigators working with nonhuman neutrophils failed to demonstrate it $(9,20)$. The observation that the fall in ATP concentration is not followed by any measurable increase in ADP or AMP concentration shows that ATP is converted beyond AMP and, therefore, that the fall in ATP concentration represents an irreversible consumption of ATP with liberation of two high energy phosphates. This total loss of adenine nucleotides is also observed when the ATP concentration is lowered by addition of 2-deoxyglucose, and it seems that whenever the consumption of ATP is greater than the generation, the products, ADP and AMP, do not ac- cumulate but are rapidly metabolized further. It should be noted that Tauber and Roberts, using ${ }^{31} \mathrm{P}$ nuclear magnetic resonance to estimate cellular ATP and ADP concentrations during stimulation with PMA and STZ, demonstrated no increase in ADP concentration despite a significant fall in ATP concentrations (24). Likewise, Newby and Holmquist (32) found that when rat neutrophils were depleted of ATP by incubation with 2-deoxyglucose, the ATP was quantitatively recovered as hypoxanthine through inosine monophosphate. It might be that the irreversible loss of adenine nucleotides observed during phagocytosis is a limiting factor in determining the extent and duration of particle ingestion. It also seems likely that the characteristics of ATP turnover are important determinants of other functions of the neutrophil such as chemotaxis, degranulation, and killing. The results presented here provide a quantitative basis for understanding the sources, generation, and utilization of energy by the human neutrophil as it performs these vital host defense functions.

\section{ACKNOWLEDGMENTS}

The authors wish to thank Professor A. Thore, Huddige Lasarett, Sweden, for most helpful advice regarding the measurements of ADP, AMP, and phosphocreatine. The expert technical assistance of Mrs. Jonna Guldberg, Mrs. Winnie Heidemann, and Mrs. Kate Sommer is gratefully acknowledged. We thank Professor V. Esmann, Aarhus, Denmark, for most helpful suggestions and critical reading of the manuscript.

This work was supported by the Danish Medical Research Council Grant No. 12-1748 and by Knud Højgaard's Fund.

\section{REFERENCES}

1. Sbarra, A. J., and M. L. Karnovsky. 1959. The biochemical basis of phagocytosis. I. Metabolic changes during the ingestion of particles by polymorphonuclear leukocytes. J. Biol. Chem. 234: 1355-1362.

2. Baldridge, C. W., and R. W. Gerard. 1933. The extra respiration of phagocytosis. Am. J. Physiol. 103: 235236.

3. Holmes, B., A. R. Page, and R. A. Good. 1967. Studies of the metabolic activity of leukocytes from patients with a genetic abnormality of phagocyte function. $J$. Clin. Invest. 46: 1422-1432.

4. Babior, B. M., R. S. Kipnes, and J. T. Curnutte. 1973. Biological defense mechanisms. The production by leukocytes of superoxide, a potential bactericidal agent. $J$. Clin. Invest. 56: 1035-1042.

5. Root, R. K., and J. A. Metcalf. 1977. $\mathrm{H}_{2} \mathrm{O}_{2}$ release from human granulocytes during phagocytosis. Relationship to superoxide anion formation and cellular catabolism of $\mathrm{H}_{2} \mathrm{O}_{2}$ : Studies with normal and cytochalasin B-treated cells. J. Clin. Invest. 60: 1266-1279.

6. Levin, K. 1973. A modified flow microcalorimeter adapted for the study of human leucocyte phagocytosis. Scand. J. Clin. Lab. Invest. 32: 67-73.

7. Cohn, Z. A., and S. I. Morse. 1960. Interactions between 
rabbit polymorphonuclear leukocytes and staphylococci. J. Exp. Med. 110: 419-443.

8. Reed, P. W., and J. Tepperman. 1969. Phagocytosis-associated metabolism and enzymes in the rat polymorphonuclear leukocyte. Am. J. Physiol. 216: 223-230.

9. Kakinuma, K. 1970. Metabolic control and intracellular pH during phagocytosis by polymorphonuclear leukocytes. J. Biochem. 68: 177-185.

10. Reiss, M., and D. Roos. 1978. Differences in oxygen metabolism of phagocytosing monocytes and neutrophils. J. Clin. Invest. 61: 480-488.

11. Borregaard, N., and H. Juhl. 1981. Activation of the glycogenolytic cascade in human polymorphonuclear leukocytes by different phagocytic stimuli. Eur. J. Clin. Invest. 11: 257-263.

12. Bergmeyer, H. U. 1974. In Methods of Enzymatic Analysis. Verlag Chemie Weinheim. Academic Press, Inc., New York. p. 1464-1467.

13. Ashcroft, S. J. H., L. C. C. Weerasinghe, J. M. Basset, and P. J. Randle. 1972. Pentose cycle and insulin release in mouse pancreatic islets. Biochem. $J$. 126: 525-532.

14. Sølling, H., and V. Esmann. 1975. A sensitive method of glycogen determination in the presence of interfering substances using the filter-paper technique. Anal. Biochem. 68: 664-668.

15. Wang, P., and V. Esmann. 1972. A new assay of phosphorylase based on the filter-paper technique. Anal. Biochem. 47: 495-500.

16. Newburger, P. E., H. J. Cohen, S. B. Rotchild, J. C. Hobbins, S. E. Malawista, and M. J. Mahoney. 1979. Prenatal diagnosis of chronic granulomatous disease. $N$. Engl. J. Med. 300: 178-181.

17. Cohen, H. J., and M. E. Chovaniec. 1978. Superoxide production by digitonin-stimulated guinea pig granulocytes. J. Clin. Invest. 61: 1088-1096.

18. Stjernhold, R. L., and R. C. Manak. 1970. Carbohydrate metabolism in leukocytes. XIV. Regulation of pentose cycle activity and glycogen metabolism during phagocytosis. J. Reticuloendothel. Soc. 8: 550-560.

19. Sbarra, A. J., and M. L. Karnovsky. 1960. The biochemical basis of phagocytosis. II. Incorporation of ${ }^{14} \mathrm{C}$-labeled building blocks into lipid, protein and glycogen of leukocytes during phagocytosis. J. Biol. Chem. 235: 2224-2229.

20. Stossel, T. P., F. Murad, R. J. Mason, and M. Vaughan.
1970. Regulation of glycogen metabolism in polymorphonuclear leukocytes. J. Biol. Chem. 245: 6228-6234.

21. Marchand, J. C., J. P. Leroux, and P. Cartier. 1972. The energy metabolism of human blood polymorphonuclear cells. Action of various effectors except hormones. Eur. J. Biochem. 31: 483-495.

22. Esmann, V. 1972. The diabetic leukocyte. Enzyme (Basel). 13: 32-55.

23. Hakansson, L., R. Hellgren, and P. Venge. 1980. Regulation of granulocyte function by hyaluronic acid. In vitro and in vivo effects on phagocytosis, locomotion, and metabolism. J. Clin. Invest. 66: 298-305.

24. Tauber, A. I., and M. F. Roberts. 1981. ${ }^{31}$ P NMR spectroscopy of phorbol-myristate-acetate stimulated polymorphonuclear human leukocytes. FEBS (Fed. Eur. Biochem. Soc.) Lett. 129: 105-108.

25. Newburger, P. E., M. E. Chovaniec, and H. J. Cohen. 1980. Activity and activation of the granulocyte superoxide generating system. Blood. 55: 85-92.

26. Segal, A. W., J. Dorling, and S. Coade. 1980. Kinetics of fusion of the cytoplasmic granules with phagocytic vacuoles in human polymorphonuclear leukocytes. Biochemical and morphological studies. J. Cell Biol. 85: 4259.

27. Roos, D., and J. S. Van der Stijl-Neijenhuis. 1980. The oxygen metabolism of human blood monocytes and neutrophils. In Mononuclear Phagocytes. p. 1119-1211. Van Furth, editor. Martinus Nijhoff Publishers, Haag.

28. Leroux, J. P., J. C. Marchand, R. Hong Tuan Ha, and $P$. Cartier. 1975. The influence of insulin on glucose permeability and metabolism of human granulocytes. Eur. J. Biochem. 58: 367-373.

29. Loike, J. D., V. F. Kozler, and S. C. Silverstein. 1979. Increased ATP and creatine phosphate turnover in phagocytosing mouse peritoneal macrophages. J. Biol. Chem. 254: 9558-9564.

30. Bridges, R. A., H. Berendes, and R. A. Good. 1959. A fatal granulomatous disease of childhood. The clinical, pathological and laboratory features of a new syndrome. J. Dis. Child. 97: 387-408.

31. Klebanoff, S. J., and R. A. Clark. 1978. The Neutrophil: Function and Clinical Disorders. North Holland Publishing Company, Amsterdam. p. 656-657.

32. Newby, A. C., and C. A. Holmquist. 1981. Adenosine production inside rat polymorphonuclear leucocytes. Biochem. J. 200: 399-403. 